\title{
Are psoriasis and psoriatic arthritis associated with chronic obstructive pulmonary disease?
}

\author{
Czy łuszczyca i łuszczycowe zapalenie stawów mają związek z przewlekłą \\ obturacyjną chorobą płuc?
}

Agnieszka B. Owczarczyk-Saczonek', Jacek Owczarczyk², Magdalena Krajewska-Włodarczyk²,
Joanna Wojtkiewicz', Waldemar Placek'

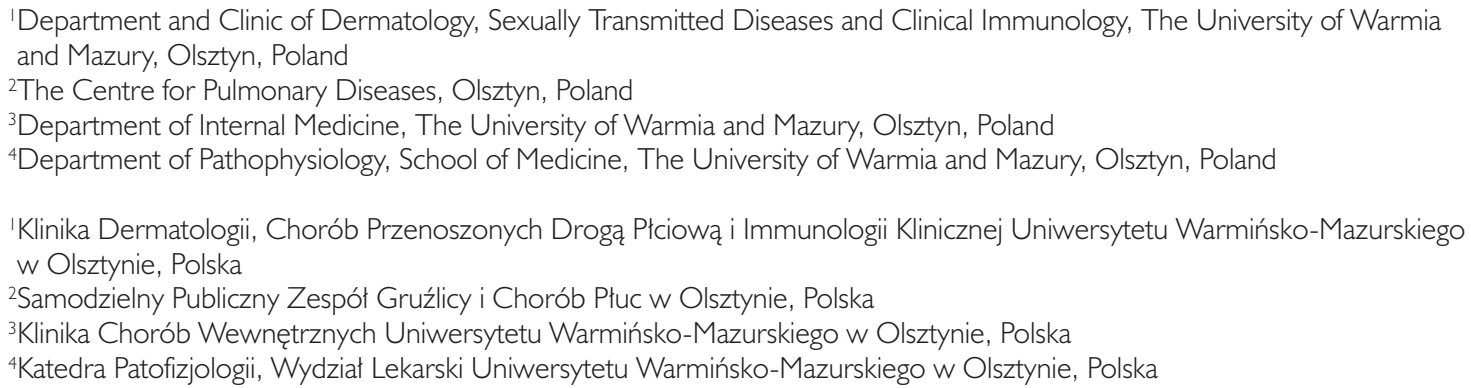

Dermatol Rev/Przegl Dermatol 2019, 106, 185-197 DOI: https://doi.org/l0.5। |4/dr.2019.85576

\section{CORRESPONDING AUTHOR/} ADRES DO KORESPONDENCJI: Agnieszka B. Owczarczyk-Saczonek Katedra i Klinika Dermatologii, Chorób Przenoszonych Drogą Płciową i Immunologii Klinicznej Miejski Szpital Zespolony Aleja Wojska Polskiego 30 10-595 Olsztyn

tel.: +48 601057800 e-mail: aganek@wp.pl

\begin{abstract}
Chronic obstructive pulmonary disease is a chronic inflammation affecting the peripheral airways and pulmonary parenchyma, leading to irreversible and progressive airflow limitation. In recent years attention has been paid to more frequent coexistence with psoriasis. Both diseases are provoked by similar factors, such as smoking, abdominal obesity, lack of physical activity, and concomitance with the metabolic syndrome. In addition, similarities in pathogenesis, regarding the roles of Th1 and Th17 can be found, resulting in an increase in the proinflammatory cytokines levels. Both in psoriasis and chronic obstructive pulmonary disease, an increased activity of proteases produced by neutrophils and adhesion molecules is observed. In addition, neutrophils are an abundant source of inflammation mediators, including reactive oxidants and lipid mediators with chemotactic activity. Awareness of the increased risk of developing chronic obstructive pulmonary disease in psoriatic patients, allows to implement preventive and therapeutic actions such as smoking cessation or treatment of the inflammatory processes.
\end{abstract}

\section{STRESZCZENIE}

Przewlekła obturacyjna choroba płuc to przewlekły stan zapalny, który obejmuje obwodowe drogi oddechowe oraz miąższ płucny i prowadzi do nieodwracalnego oraz postępującego ograniczenia przepływu powietrza. W ostatnich latach zwraca się uwagę na częstsze współistnienie przewlekłej obturacyjnej choroby płuc z łuszczycą. Obie choroby są wywoływane przez podobne czynniki, takie jak palenie tytoniu, otyłość brzuszna i brak aktywności fizycznej, oraz wiążą się z zespołem metabolicznym. Ponadto można się doszukać podobieństw elementów patogenezy dotyczących roli Th1 i Th17, co skutkuje wzrostem stężenia 
cytokin prozapalnych. Zarówno w łuszczycy, jak i przewlekłej obturacyjnej chorobie płuc obserwuje się zwiększoną aktywność proteaz produkowanych przez neutrofile i cząsteczek adhezyjnych. Dodatkowo neutrofile są obfitym źródłem mediatorów stanu zapalnego, w tym reaktywnych utleniaczy, mediatorów lipidowych o aktywności chemotaktycznej. Świadomość podwyższonego ryzyka rozwoju przewlekłej obturacyjnej choroby płuc u pacjentów z łuszczycą pozwala na podjęcie działań profilaktycznych i terapeutycznych oraz kontrolowanie czynników ryzyka, takich jak zaprzestanie palenia tytoniu i leczenie procesu zapalnego.

Key words: psoriasis, chronic obstructive pulmonary diseases, tobacco smoking.

Słowa kluczowe: łuszczyca, przewlekła obturacyjna choroba płuc, palenie papierosów.

\section{INTRODUCTION}

Chronic obstructive pulmonary disease (COPD) is a chronic inflammation affecting the peripheral airways and pulmonary parenchyma, leading to irreversible and progressive airflow limitation. Recent epidemiological examinations have indicated a frequent co-existence of psoriasis and COPD. However, the connection fails to have been well-analysed. Both diseases are provoked by similar factors such as smoking, abdominal obesity, lack of physical activity, and concomitance of the metabolic syndrome [1-3].

\section{METHODS FOR SEEKING REFERENCES}

The paper includes data from overview of literature. Evaluated articles were identified by searching PubMed using the following phrases: psoriasis, chronic obstructive pulmonary disease, and COPD. The search was conducted till the $1^{\text {st }}$ September 2018. Twenty-three articles were found, and seventeen of them were analysed.

\section{EPIDEMIOLOGICAL DATA}

Epidemiological study conducted by Dreiher et al. shows that COPD is more frequent in psoriatic patients than in the control group (5.7 vs. 3.6\%) [4] Also, conclusions from an American cohort study (National Health and Wellness Survey) confirmed a higher frequency of COPD incidence in patients suffering from psoriasis (odds ratio (OR) 1.68) [5]. Then, a Taiwanese population study showed that psoriatic patients were subject to 2.35 times higher risk for COPD development that patients in the control group during an 18-month-long observation;

\section{WPROWADZENIE}

Przewlekła obturacyjna choroba płuc (POChP) to przewlekły stan zapalny, który obejmuje drogi oddechowe oraz miąższ płucny i prowadzi do nieodwracalnego i postępującego ograniczenia przepływu powietrza. Badania epidemiologiczne z ostatnich lat wskazują na częstsze współwystępowanie łuszczycy i POChP. Związek ten nie jest jednak dobrze zbadany. Obie choroby są wywoływane przez podobne czynniki, takie jak palenie tytoniu, otyłość brzuszna i brak aktywności fizycznej, oraz wiążą się z zespołem metabolicznym [1-3].

\section{METODY WYSZUKIWANIA PIŚMIENNICTWA}

Niniejsza praca zawiera dane pochodzące z przeglądu piśmiennictwa. Artykuły poddane ocenie zostały zidentyfikowane poprzez wyszukanie w bazie PubMed terminów psoriasis, chronic obstructive pulmonary disease i COPD. Wyszukiwanie przeprowadzono do 1 września 2018 roku. Znaleziono 23 artykuły, a analizie poddano 17 .

\section{DANE EPIDEMIOLOGICZNE}

Badanie epidemiologiczne przeprowadzone przez Dreihera i wsp. wskazuje, że POChP jest częstsza u pacjentów z łuszczycą niż w grupie kontrolnej (5,7 vs $3,6 \%$ ) [4]. Wnioski z amerykańskiego badania kohortowego (National Health and Wellness Survey) również potwierdziły większą częstość występowania POChP u pacjentów z łuszczycą [iloraz szans (odds ratio - OR) 1,68] [5]. Natomiast w tajwańskim badaniu populacyjnym wykazano, że w czasie 18-miesięcznej obserwacji u chorych na łuszczycę występuje 2,35-krotnie większe ryzyko rozwoju POChP niż u pacjentów w grupie kon- 
the conclusion related to men and patients above $50 \mathrm{y} / \mathrm{o}$ in particular [2].

Concomitance of psoriasis and COPD was more often confirmed in the elderly (above $55 \mathrm{y} / \mathrm{o}$ ) and concerned men more frequently $[2,4]$. Interestingly, these patients suffered from severe psoriasis (required phototherapy or general treatment) rather than mild psoriasis (using local therapy only) (hazard ratio (HR) 2.81 vs. 2.22) [2]. In addition, the patients led an unhealthy lifestyle associated with smoking, diabetes, and obesity. Socio-economic status did not influence the co-existence of both diseases [2, 4]. However, a significant difference in co-existence in patients below $50 \mathrm{y} / \mathrm{o}$ was not confirmed [2]. An interesting dependence was confirmed in the Taiwanese study: patients suffering from psoriasis and COPD more frequently suffered from arterial hypertension [6]. Further studies in order to examine epidemiology and possible pathophysiological association between these two disease entities are necessary.

The data was confirmed in meta-analyses. Ungprasert et al. showed that in psoriatic patients the risk for COPD is 1.45 times higher [7]. Then, a meta-analysis of Li et al., which involved 13,000 patients from four observational studies, also revealed this association, however, the risk was higher $(\mathrm{OR}=1.90)$, especially in patients with a severe form of the disease $(\mathrm{OR}=$ 2.15). Additionally, the authors analysed smoking as a risk factor for developing both diseases. Collected data revealed a significant connection between psoriatic patients and the control group with regard to frequency of being a smoker $(\mathrm{OR}=2.05)[4,8,9]$.

Al-Mutairi et al. showed a statistically insignificant higher frequency of COPD incidence in over 12,000 psoriatic patients; however, in a study involving only patients with psoriatic arthritis, COPD was the fifth most common concomitant disease, after hypertension, obesity, diabetes, and kidney diseases [8].

In a Canadian 30-year-long observational study, involving 428 patients, pulmonary diseases constituted a reason for death of $21 \%$ of patients suffering from psoriatic arthritis, including $6.4 \%$ due to COPD [10].

Unfortunately, there is no data illustrating frequency of psoriasis incidence in COPD patients. Epidemiological studies evaluating concomitance of other disease, the following are listed most often: cardio-vascular diseases, lung cancer, osteoporosis, obstructive sleep apnea (OSA), diabetes, gastroesophageal reflux, and depression [11]. However, in many studies psoriasis failed to be treated as a disease sought in COPD patients $[11,12]$.

There are only few studies comparing pulmonary function tests. Balci et al. assessed spirometric parameters in 96 psoriatic patients as compared with 60 individuals from the control group with regard trolnej, dotyczyło to szczególnie mężczyzn i pacjentów powyżej 50. roku życia [2].

Współistnienie łuszczycy i POChP częściej stwierdzono u osób starszych (powyżej 55. roku życia), zwłaszcza mężczyzn [2, 4]. Ponadto u tych pacjentów łuszczyca miała raczej cięższy przebieg (wymagała włączenia fototerapii lub leczenia ogólnego) niż łagodny (stosowanie tylko terapii miejscowej) [ryzyko względne (hazard ratio - HR) 2,81 vs 2,22] [2]. Dodatkowo pacjenci prowadzili niezdrowy tryb życia, palili tytoń, występowały u nich cukrzyca i otyłość. Status socjoekonomiczny nie wpływał na współwystępowanie obu schorzeń $[2,4]$. Nie stwierdzono natomiast istotnie częstszego współwystępowania tych chorób u pacjentów poniżej 50. roku życia [2]. Ciekawą zależność wykazano w badaniach z Tajwanu: pacjenci z łuszczycą i POChP znacznie częściej chorowali na nadciśnienie tętnicze [6]. Konieczne są dalsze badania dotyczące epidemiologii i możliwych patofizjologicznych powiązań między tymi jednostkami chorobowymi.

Dane te potwierdziły metaanalizy. Ungprasert i wsp. wykazali, że u pacjentów z łuszczycą występowało 1,45-krotnie podwyższone ryzyko rozwoju POChP [7]. Natomiast metaanaliza Li i wsp., która objęła ponad 13 tysięcy pacjentów w czterech badaniach obserwacyjnych, również wykazała ten związek, ale ryzyko było większe $(\mathrm{OR}=1,90)$, zwłaszcza wśród pacjentów z ciężką postacią choroby $(\mathrm{OR}=2,15)$. Dodatkowo autorzy przeanalizowali palenie papierosów jako czynnik ryzyka rozwoju obu chorób. Zebrane dane potwierdziły znaczące powiązanie między pacjentami z łuszczycą i grupą kontrolną w zakresie częstości występowania nałogu palenia tytoniu $(\mathrm{OR}=2,05)[4,8,9]$.

Al-Mutairi i wsp. stwierdzili nieistotną statystycznie wyższą częstość występowania POChP u ponad 12 tysięcy chorych na łuszczycę, ale $\mathrm{w}$ badaniu obejmującym tylko pacjentów z łuszczycowym zapaleniem stawów POChP była piątą najczęściej spotykaną chorobą współistniejącą - po nadciśnieniu, otyłości, cukrzycy i chorobach nerek [8].

W kanadyjskim 30-letnim badaniu obserwacyjnym, obejmującym 428 pacjentów, choroby układu oddechowego stanowiły przyczynę zgonów u 21\% chorych na łuszczycowe zapalenie stawów, w tym w 6,4\% była to POChP [10].

Niestety brakuje danych dotyczących częstości występowania łuszczycy u pacjentów z POChP. W badaniach epidemiologicznych oceniających współwystępowanie innych chorób wymienia się najczęściej choroby sercowo-naczyniowe, raka płuc, osteoporozę, obturacyjny bezdech senny, cukrzycę, refluks żołądkowo-przełykowy i depresję [11]. W wielu pracach łuszczyca nie była jednak brana pod uwage jako schorzenie, którego poszukiwano u pacjentów z POChP [11, 12].

Niewiele jest prac porównujących czynnościowe badania płuc. Balci i wsp. ocenili parametry spiro- 
to their sex and age. Mean ratio of forced expiratory volume in $1 \mathrm{~s} /$ forced vital capacity $\left(\mathrm{FEV}_{1} / \mathrm{FVC}\right)$ and FEF $25-75 \%$ (forced expiratory flow) was significantly lower in psoriatic patients than in the control group [1]. $\mathrm{FEV}_{1} / \mathrm{FVC}$ is a reliable and important parameter for diagnosing a kind of ventilation disorder. Its value below 0.7 ( $<70 \%$ of the absolute value) allows for identifying an obstruction $[1,13,14]$. Abnormal parameters were confirmed in $7.3 \%$ of patients, what may reflect a tendency for psoriatic patients to develop COPD [1]. Then, FEF 25-75\% is a mean forced expiratory volume between 25 and $75 \%$ of FVC value, which indicated an obstruction of small bronchi ( $<2 \mathrm{~mm}$ in diameter) $[1,14]$. A significant relation between psoriasis and FEF $25-75 \%$ may also suggest that psoriasis is an independent risk factor for developing small airway obstruction. However, the study did not confirm a significant relationship between lesion exacerbation (PASI) or disease duration and any of spirometric parameters [1].

Another Danish study by Hansen et al. evaluated history with regard to pulmonary diseases and spirometric values in over 20,000 psoriatic patients, and compared them with the results of the control group. The group of psoriatic patients was confirmed to experience the following in the past 10 years: higher body mass index (BMI), C-reactive protein (CRP), frequent addiction to nicotine, more frequent suffocation, and episodes of pneumonia. Moreover, $\mathrm{FEV}_{1}$ and $\mathrm{FEV}_{1} / \mathrm{FVC}$ were lower. FVC values were similar in both groups. Having performed an additional correction for smoking, only a decrease in $\mathrm{FEV}_{1}$ was statistically significant, while a percentage of individuals with a decreased $\mathrm{FEV}_{1} / \mathrm{FVC}<0.70$, what is typical for COPD, increased in the group of psoriatic patients [15].

It should be emphasized that psoriasis and COPD have similar risk factors, especially smoking, and thus, in statistical studies these factors may disturb the connection between these two diseases, what needs to be taken into consideration [2].

\section{PATHOGENETIC ASSOCIATION BETWEEN PSORIASIS AND COPD}

\section{Smoking and the risk for developing psoriasis and COPD}

Smoking cigarettes is a strong factor causing the appearance of disease lesions. A risk for psoriasis in smokers with present HLA-Cw6 is 11 times higher than in non-smoker with no HLA0Cw6, and the risk increase by 20 times in individuals who experience additional stressful life events [16]. There exists a correlation between the number of pack-years and the risk for psoriasis, even in case of passive smokers. metryczne u 96 chorych na łuszczycę w porównaniu z 60 osobami z grupy kontrolnej dobranej pod względem płci i wieku. Średni stosunek natężonej objętości wydechowej 1-sekundowej do natężonej pojemności życiowej $\left(\mathrm{FEV}_{1} / \mathrm{FVC}\right)$ i natężony przepływ wydechowy w wybranych momentach natężonego wydechu (FEF 25-75\%) był znacząco niższy u chorych na łuszczycę niż w grupie kontrolnej [1]. Wskaźnik FEV FVV $_{1}$ jest wiarygodnym i ważnym parametrem spirometrycznym służącym do rozpoznania rodzaju zaburzeń wentylacji. Jego wartość poniżej 0,7 (<70\% wartości bezwzględnej) pozwala rozpoznać obturację [1, 13, 14]. Nieprawidłowy wskaźnik stwierdzono u 7,3\% pacjentów, co może odzwierciedlać tendencję do rozwoju POChP u pacjentów z łuszczycą [1]. Natomiast FEF $25-75 \%$ to średni wymuszony przepływ powietrza wydechowego pomiędzy 25\% a 75\% wartości FVC, który wskazuje na niedrożność małych oskrzeli $(<2 \mathrm{~mm}$ średnicy) [1, 14]. Istotny związek między łuszczycą a FEF 25-75\% może również sugerować, że łuszczyca jest niezależnym czynnikiem ryzyka rozwoju niedrożności drobnych dróg oddechowych. Nie stwierdzono jednak w badaniu żadnego istotnego związku między nasileniem zmian (PASI) lub czasem trwania choroby a jakimkolwiek parametrem spirometrycznym [1].

W kolejnym badaniu duńskim Hansena i wsp. porównano informacje dotyczące występowania schorzeń układu oddechowego i wartości spirometryczne u ponad 20 tysięcy chorych na łuszczycę z wynikami w grupie kontrolnej. Oprócz większych wartości wskaźnika masy ciała (body mass index - BMI), stężenia białka C-reaktywnego (C-reactive protein - CRP) i częstszego uzależnienia od nikotyny, u pacjentów z łuszczycą stwierdzono częstsze występowanie duszności i epizodów zapalenia płuc w czasie ostatnich 10 lat. Parametry spirometryczne $\left(\mathrm{FEV}_{1}\right.$ i wskaźnik $\left.\mathrm{FEV}_{1} / \mathrm{FVC}\right)$ były również niższe. Wartości FVC były podobne w obu grupach. Po dodatkowej korekcie dotyczącej nałogu palenia tytoniu tylko zmniejszenie $\mathrm{FEV}_{1}$ pozostało statystycznie istotne, a także odsetek osób ze zmniejszonym wskaźnikiem $\mathrm{FEV}_{1} / \mathrm{FVC}<0,70$, co jest typowe dla POChP, był zwiększony u chorych na łuszczycę [15].

Należy podkreślić, że łuszczyca i POChP mają podobne czynniki ryzyka, zwłaszcza palenie tytoniu, dlatego należy wziąć pod uwagę, że w badaniach statystycznych czynniki te mogą zakłócać związek między tymi chorobami [2].

\section{ZWIAZZKI PATOGENETYCZNE ŁUSZCZYCY I POCHP}

\section{Palenie papierosów a ryzyko wystąpienia łuszczycy i POChP}

Palenie papierosów jest silnym czynnikiem wywołującym wysiew zmian chorobowych. Ryzyko 
The risk for developing the disease would drop to zero after 20 years of having stopped smoking [17]. Fortes et al. concluded that smoking over 20 cigarettes daily cased twice as high risk for developing psoriasis than smoking 10 cigarettes per day [18]. A meta-analysis of 28 studies regarding smoking that included 146,000 psoriatic patients and 529,000 patients without psoriasis showed that smoking increases the risk for the disease $(\mathrm{OR}=1.78)$ also in former smokers $(\mathrm{OR}=1.62)$ [19]. This habit exerts an influence also on the course of the disease: in $77 \%$ of non-smoking patients there was a period remission of the disease, whereas only $8.7 \%$ of regular smokers experiences that [18].

Smoking is the main risk factor for COPD development, but only $20 \%$ of smokers actually develop this disease, what suggests that genetic predispositions play a role here $[20,21]$. Inhaling cigarette smoke causes lung damage by oxidative stress and induction of tumour necrosis factor $\alpha$ (TNF- $\alpha$ ) production by alveolar macrophages, what in turn may lead to exacerbation of airway inflammation and systemic damage of organs $[2,22]$. The cytokine leads to an increase in activity of inducible nitric oxide synthase (iNOS) that is responsible for formation of nitric oxide (NO) from arginine [23]. It has a special influence on fractional exhaled nitric oxide (FeNO) in patients with COPD. Fractional exhaled NO has been accepted in literature as an indirect marker of pulmonary inflammation, and is currently used in clinical monitoring and treatment of inflammatory conditions of the respiratory system [23]. Concentration of the exhaled NO is proportional to the level of inflammation confirmed in the bronchial wall, eosinophilia in induced sputum, and bronchial hyperresponsiveness. An increase in FeNO concentration in psoriatic patients may increase the risk for development of COPD $[1,24]$. Recent studies have showed that FeNO values were increased in non-treated psoriatic patients, and probably reflected subclinical pulmonary inflammation, which became normalized after the remission of psoriatic lesions. Persistent inflammation may cause a change in a microstructure of airways, while increasing the risk for development of pulmonary diseases, such as COPD or asthma $[1,23]$.

Additionally, smoking increases the number of circulating neutrophils, involving sequestration of these cells in pulmonary capillaries. Both sputum and bronchoalveolar lavage (BAL) from COPD patients contain a large number of neutrophils [24].

An inflammation with T-lymphocytes in the lungs that persists many years after an individual has ceased smoking is of key importance in COPD development. Hence, some authors suggest that it may be an autoimmune disease caused by smoking [25]. It wystąpienia łuszczycy u palaczy z obecnym HLA-Cw6 jest 11-krotnie większe niż u niepalących bez HLA-Cw6 i wzrasta 20-krotnie u osób, u których dodatkowo występują stresujące zdarzenia życiowe [16]. Istnieje zależność między liczbą paczkolat a ryzykiem wystąpienia łuszczycy, nawet w przypadku biernych palaczy. Ryzyko rozwoju choroby zmniejsza się do 0 po 20 latach zaprzestania palenia [17]. Fortes i wsp. stwierdzili, że wypalanie powyżej 20 papierosów dziennie powodowało 2-krotnie większe ryzyko zachorowania na łuszczycę niż 10 papierosów dziennie [18]. Metaanaliza 28 badań dotyczących palenia, która objęła 146 tys. pacjentów z łuszczycą i 529 tys. bez łuszczycy, wykazała, że palenie zwiększa ryzyko wystąpienia tej choroby $(\mathrm{OR}=1,78)$ także u byłych palaczy $(\mathrm{OR}=1,62)$ [19]. Nałóg ten wpływa także na przebieg schorzenia: u 77\% niepalących pacjentów występowała okresowa remisja choroby, a wśród regularnych palaczy tylko u 8,7\% [18].

Palenie papierosów jest głównym czynnikiem ryzyka rozwoju POChP, ale tylko u 20\% palaczy rzeczywiście występuje ta choroba, co sugeruje, że znaczenie mają również predyspozycje genetyczne [20, 21]. Wdychanie dymu papierosowego powoduje uszkodzenie płuc poprzez stres oksydacyjny i indukowanie wytwarzania czynnika martwicy nowotworów $\alpha$ (tumor necrosis factor- $\alpha$ - TNF- $\alpha$ ) przez makrofagi pęcherzykowe, co z kolei może zaostrzać zapalenie dróg oddechowych i ogólnoustrojowe niszczenie narządów [2, 22]. Cytokina ta prowadzi m.in. do zwiększenia aktywności indukowalnej formy syntazy tlenku azotu (inducible nitric oxide synthase - iNOS), która odpowiada za powstawanie tlenku azotu (NO) $\mathrm{z}$ argininy [23]. Ma ona szczególny wpływ na frakcję wydychanego tlenku azotu (fractional exhaled nitric oxide - FeNO) u pacjentów z POChP. Frakcyjny wydychany $\mathrm{NO}$ został zaakceptowany w piśmiennictwie jako pośredni marker zapalenia dróg oddechowych i jest obecnie stosowany w klinicznym monitorowaniu oraz leczeniu stanów zapalnych układu oddechowego [23]. Stężenie wydychanego NO jest proporcjonalne do stopnia zapalenia stwierdzanego w ścianie oskrzeli, liczby eozynofilów w indukowanej plwocinie i nadreaktywności oskrzeli. Wzrost stężenia FeNO u pacjentów z łuszczycą może zwiększyć ryzyko wystąpienia POChP $[1,24]$. W niedawnych badaniach stwierdzono podwyższone wartości FeNO u nieleczonych chorych na łuszczycę, co prawdopodobnie odzwierciedla subkliniczne zapalenie dróg oddechowych, które znormalizowało się po ustąpieniu zmian łuszczycowych. Utrzymujący się stan zapalny może powodować zmianę mikrostruktury dróg oddechowych, zwiększając ryzyko rozwoju chorób układu oddechowego, takich jak POChP i astma [1,23].

Palenie papierosów powoduje także wzrost liczby krążących neutrofilów, z sekwestracją tych komórek 
is confirmed by the fact that it develops in $5 \%$ of patients who have never smoked [25].

\section{Immunological profile of the inflammation in psoriasis and COPD}

Recent studies regarding COPD pathogenesis reveal similarities in inflammatory mechanism of both diseases engaging Th1 and Th17 lines, what results in an increase of pro-inflammatory cytokines' concentration: IL-1, IL-6, IL-8, IL-17, and TNF- $\alpha$. Moreover, it was confirmed that sputum and BAL bronchoalveolar fluid in COPD patients showed an increased expression of IL-17 and other pro-inflammatory cytokines listed above [26-28].

Tumor necrosis factor $\alpha$ contributes to development of inflammation in COPD by stimulating expression of adhesion molecules leading to an inflow of inflammatory cells and an increased production of extracellular matrix metalloproteinases and tenascin, which promote tissue damage and their remodelling [26]. It is likely that genetic variations associated with TNF- $\alpha$ may exert an influence on susceptibility to COPD, and also lung functional parameters $[2,26]$. Dysregulation of TNF- $\alpha$ production, resulting in development of neutrophil inflammation, may influence the COPD phenotype and its progression [2].

Chang et al. analysed IL-17A and IL-17F expression as well as phenotype of cells that produced them in bronchial biopsies sampled from COPD patients. IL-17F immunoreactivity was in those patients significantly higher as compared with individuals from the control group. In the submucosal stratum the absolute number of cells producing both cytokines was higher in the sick. mRNA expression of IL-17A and IL-17F was associated with not only CD4 cells, but also CD8 [26]. The study emphasizes that Th17-produced cytokines may play an important role in COPD pathogenesis, while providing a possibility to use this mechanism as the basis for new therapeutic options [26]. Then, the study of Roos et al. proved a connection between IL-17A and IL-17F expression in pulmonary tissue and COPD stage and functional test values. Cytokine concentration was significantly elevated in severe and very severe COPD as compared with smokers without COPD and non-smoker without COPD. IL-17A may contribute to advancement of the disease and secondary appearance of lymphoid follicles in lung, what is characteristic for the terminal inflammation stage in COPD, by activating the expression of chemokine ligand - CXC12 [29].

IL-17A may also induce production of mucin 5AC (a biomarker for chronic obstructive pulmonary disease) in human bronchial epithelium, whereas transgenic IL-17 overexpression in alveoli causes pneumonia with a phenotype similar to COPD [26, 30]. Moreover, IL-17A overexpression stimulates w naczyniach włosowatych płuc. Zarówno plwocina, jak i popłuczyny oskrzelowo-peccherzykowe (bronchoalveolar lavage - BAL) od pacjentów z POChP zawierają dużą liczbę neutrofilów [24].

Zapalenie z udziałem limfocytów T w płucach, które utrzymuje się przez wiele lat po zaprzestaniu palenia, jest ważne w rozwoju POChP. Część autorów sugeruje, że może być ona chorobą autoimmunologiczną wywołaną przez palenie papierosów [25]. Potwierdza to fakt, że POChP występuje u 5\% osób, które nigdy nie paliły [25].

\section{Profil immunologiczny zapalenia w łuszczycy i POChP}

Ostatnie badania dotyczące patogenezy POChP wykazały podobieństwa mechanizmu zapalenia w obu chorobach angażujących linie Th1 i Th17, co skutkuje wzrostem stężenia cytokin prozapalnych, takich jak IL-1, IL-6, IL-8, IL-17 i TNF- $\alpha$. Stwierdzono również, że plwocina i BAL pacjentów z POChP wykazują zwiększoną ekspresję IL-17 i innych wymienionych powyżej cytokin prozapalnych [26-28].

Czynnik martwicy nowotworów a przyczynia się do rozwoju zapalenia w POChP poprzez stymulację ekspresji cząsteczek adhezyjnych prowadzących do napływu komórek zapalnych i zwiększonego wytwarzania metaloproteinaz macierzy zewnątrzkomórkowej oraz tenascyny, które sprzyjają uszkodzeniu tkanek i ich przebudowie [26]. Prawdopodobnie warianty genetyczne związane z TNF- $\alpha$ mogą wpływać na podatność na POChP, a także na parametry czynnościowe płuc $[2,26]$. Dysregulacja produkcji TNF- $\alpha$ skutkująca rozwojem neutrofilowego zapalenia może wpływać na fenotyp POChP i jej progresję [2].

Chang i wsp. przeanalizowali ekspresję IL-17A i IL-17F, a także fenotyp wytwarzających je komórek w biopsjach oskrzelowych pobranych od pacjentów z POChP. Immunoreaktywność IL-17F była u nich znacząco wyższa $\mathrm{w}$ porównaniu z osobami z grupy kontrolnej. W warstwie podśluzowej także absolutna liczba komórek wytwarzających obie cytokiny była większa u chorych. Ekspresja mRNA IL-17A i IL-17F była związana nie tylko z komórkami CD4, lecz także CD8 [26]. Badanie to podkreśla, że cytokiny produkowane przez Th17 mogą odgrywać ważną rolę w patogenezie POChP, co umożliwia wykorzystanie tego mechanizmu jako podstawy dla nowych opcji terapeutycznych [26]. Natomiast Roos i wsp. w swoim badaniu udowodnili związek pomiędzy ekspresją IL-17A i IL-17F w tkance płucnej a stadium POChP i wartościami badań czynnościowych. Stężenie cytokin było znacząco podwyższone w ciężkiej i bardzo ciężkiej postaci POChP w porównaniu z palaczami bez POChP i niepalącymi bez POChP. IL-17A może się przyczyniać do postępu choroby i wtórnego powstawania grudek limfoidalnych w płucach, co jest 
neutrophil accumulation and activation, as well as an increase in proteases secreted by them that destroy respiratory structures. Thus, low efficacy of glucocorticosteroids in this disease, especially in patients with IL-17 overexpression, can be explained [26, 31].

Another common component of inflammation in both diseases is neutrophil hyperactivity and NETosis (neutrophil extracellular trap). It is an alternative method for antibacterial protection. Neutrophil are capable of releasing outside their cell membrane condensed chromatin with histones, neutrophil elastase, which traps extracellular bacteria in a net-trap [32, 33]. NET release results in a high local concentration of antimicrobial peptides, including myeloperoxidase, neutrophil elastase, and cathelicidin LL-37 [33, 34].

An increased activity of NETosis is confirmed in psoriasis. Sera of psoriatic patients showed an increased ability to induce NET formation in controlled neutrophils, but a normal ability for NET degradation. In addition, the number of NET complexes in peripheral blood correlated with disease exacerbation [34]. The phenomenon is also present in disease exanthemata, where NET induces mRNA in response to bacterial infections [34].

Chronic obstructive pulmonary disease was confirmed to exhibit a greater number of NET complexes consisting in elastase-DNA and histone-elastase dependent on the disease severity, frequency of exacerbations and $\mathrm{FEV}_{1}$. Ex vivo neutrophil phagocytosis from the respiratory track was decreased in patients with increased number of NET complexes in sputum. Additionally, a loss of variety in respiratory tract microflora was observed; Haemophilus species dominated [32].

Abnormal neutrophil inflammation is characteristic for COPD, and neutrophil contribute to the respiratory tract damage by releasing proteases and reactive oxygen species, leading to loss of alveoli, increased mucous production, and mucociliary dysfunction. Physiologically speaking, activated neutrophils undergo apoptosis fast and are removed by alveolar macrophages in a non-inflammatory way [32].

Both in psoriasis and COPD an increased activity of proteases produced by neutrophils (elastase, cathepsin G, neutral serine proteases, and extracellular matrix metalloproteinases) and adhesion molecules (e.g. ICAM-1, E-selectin, CD18) are observed $[1,9,35]$. It is a result of pro-inflammatory cytokine stimulation of airway epithelium (IL-17A, among others) that releases chemoattractants: CXCL1, CXCL5, CXCL6, CXCL8 (IL-8), and CCL5 (RANTES) [26]. Furthermore, it turns out that cigarette smoke damages epithelial cells that release "danger signals" acting as ligands for Toll-like receptors (TLR) [36]. These phenomena initiate production of chemokines and pro-inflammatory cytokines. Additionally, oxidative charakterystyczne dla końcowego stadium zapalenia w POChP, poprzez aktywację ekspresji ligandu chemokiny CXC12 [29].

IL-17A może również indukować wytwarzanie mucyny 5AC (biomarker przewlekłego zapalenia dróg oddechowych) w ludzkich komórkach nabłonka oskrzeli, a transgeniczna nadekspresja IL-17 w pęcherzykach płucnych wywołuje zapalenie płuc $\mathrm{z}$ fenotypem podobnym do POChP $[26,30]$. Ponadto nadekspresja IL-17A stymuluje gromadzenie się i aktywację neutrofilów oraz zwiększenie ilości wydzielanych przez nie proteaz niszczących struktury oddechowe. Tłumaczy to małą skuteczność glikokortykosteroidów w tej chorobie, zwłaszcza u pacjentów z nadekspresją IL-17 [26, 31].

Kolejnym wspólnym elementem zapalenia w obu chorobach jest nadaktywność neutrofilów i zjawisko NETozy (neutrophil extracellular trap). Jest to alternatywna metoda obrony przeciwbakteryjnej. Neutrofile są zdolne do wyrzucania poza błonę komórkową zdekondensowanej chromatyny z histonami, elastazą neutrofilową, która zatrzymuje bakterie zewnątrzkomórkowe w sieci - pułapce [32, 33]. Uwalnianie NET skutkuje dużym lokalnym stężeniem peptydów przeciwdrobnoustrojowych, w tym mieloperoksydazy, elastazy neutrofilowej i katelicydyny LL-37 [33, 34].

W łuszczycy stwierdza się zwiększoną aktywność NETozy. Surowice chorych na łuszczycę wykazały zwiększoną zdolność do indukowania tworzenia NET w kontrolnych neutrofilach, ale normalną zdolność degradacji NET. Dodatkowo ilość kompleksów NET w krwi obwodowej koreluje z nasileniem choroby [34]. Zjawisko to jest również obecne w wykwitach chorobowych, gdzie NET indukuje mRNA w odpowiedzi na infekcje bakteryjne [34].

W POChP stwierdzono zwiększoną ilość kompleksów NET składających się z elastazy-DNA i elastazy histonowej, zależną od nasilenia choroby, częstości zaostrzeń i FEV 1 . Fagocytoza neutrofilów z dróg oddechowych ex vivo była zmniejszona u pacjentów ze wzrostem ilości kompleksów NET w plwocinie. Dodatkowo zaobserwowano utratę różnorodności mikroflory dróg oddechowych z przewagą gatunku Haemophilus [32].

Nieprawidłowe zapalenie neutrofilowe jest charakterystyczne dla POChP, a neutrofile przyczyniają się do uszkodzenia dróg oddechowych poprzez uwalnianie proteaz i reaktywnych form tlenu, co prowadzi do utraty pęcherzyków, zwiększonej produkcji śluzu i dysfunkcji śluzowo-rzęskowej. Fizjologicznie aktywowane granulocyty obojętnochłonne szybko ulegają apoptozie i są usuwane przez makrofagi pęcherzykowe w sposób niezapalny [32].

Zarówno w łuszczycy, jak i POChP obserwuje się zwiększoną aktywność proteaz produkowanych przez neutrofile (elastaza, katepsyna G, obojętna 
stress, caused by smoking, and an increased tendency for endothelial and epithelial cell apoptosis disturb physiological mechanisms of respiratory tract regenerations that are necessary to overcome permanent injury caused by cigarette smoke and dust triggering COPD [36]. Moreover, apoptotic residues may favour further inflammatory conditions and immunological reaction [36]. However, in case of psoriasis there exists a reverse phenomenon: psoriatic keratinocytes are particularly resistant to apoptosis, and the exanthemata are confirmed to have Bcl-xL overexpression stimulated by TNF- $\alpha$ of decreased keratinocyte apoptosis [37]. It should be highlighted that neutrophils only are a rich source of inflammation mediators, including reactive oxygen species (ROS), lipid mediators with chemotactic activity [38].

TLR stimulation influences dendritic cells that, similarly to their role in psoriasis, activate adaptive mechanisms of immune response. In the presence of IL-12 or IL-23, active Th1 and Th17 develop from naive lymphocytes [39]. Furthermore, it was concluded that a subset of dendritic cells CD11c+, termed TIP-DC (producing TNF- $\alpha$ and inducible nitric oxide synthase) and closely related to pathogenesis of psoriasis, may also be a factor contributing to COPD development $[2,40]$. TIP-DCs secrete also IL-20 and IL-23 that activate keratinocytes and cause proliferation of Th17 lymphocytes producing IL-17 [40].

Like in psoriasis, a decreased number of Treg cells was confirmed [28]. Smokers with COPD and emphysema had a considerably smaller number of them and showed a lower mRNA expression for FOXP3 in lungs [39].

\section{Role of infection in provoking psoriasis and COPD}

Significance of infection as a provoking factor in appearance of psoriatic lesions in well known and explained by a "superantigen theory". A classic example is a disease provocation by M protein produced by Streptococus pyogenes. It is proved by a reduction of skin lesions, and even disease remission after tonsillectomy [41, 42]. Other provoking infectious factors that have been confirmed include: Staphylococcus aureus, fungi (Malassezia, Candida albicans) and viruses (papillomavirus, retroviruses) [41].

It should be highlighted that chronic inflammation and an increased tendency for bacterial infections in individuals suffering from COPD are factors releasing psoriatic inflammation in superantigen mechanism [42]. Bacterial colonization exists in both stable COPD and during exacerbation periods. Pneumococci are most frequently confirmed: Haemophilus influenzae, Moraxella catarrhalis, and Staphylococcus aureus [21]. Between $50 \%$ and $80 \%$ of Staphylococcus aureus isolates are positive with regard to at least one superantigen gene, and almost $50 \%$ shows su- proteaza serynowa i metaloproteinazy macierzy zewnątrzkomórkowej) i cząsteczek adhezyjnych (np. ICAM-1, E-selektyna, CD18) [1, 9, 35]. Jest to skutek stymulacji cytokinami prozapalnymi nabłonka dróg oddechowych (m.in. IL-17A), który uwalnia chemoatraktanty: CXCL1, CXCL5, CXCL6, CXCL8 (IL-8) i CCL5 (RANTES) [26]. Okazuje się również, że dym papierosowy uszkadza komórki nabłonkowe, które uwalniają "sygnały niebezpieczeństwa”, działające jako ligandy dla receptorów Toll-podobnych (TLR) [36]. Zjawiska te uruchamiają produkcję chemokin i cytokin prozapalnych. Dodatkowo stres oksydacyjny spowodowany paleniem papierosów oraz zwiększona tendencja do apoptozy komórek śródbłonka i nabłonka zakłócają fizjologiczne mechanizmy regeneracji dróg oddechowych, które są niezbędne do przezwyciężenia trwałego urazu spowodowanego przez dym papierosowy i pyły wywołujące POChP [36]. Ponadto szczątkowe pozostałości apoptotyczne mogą sprzyjać dalszym stanom zapalnym i reakcji immunologicznej [36]. W przypadku łuszczycy występuje odwrotne zjawisko: łuszczycowe keratynocyty są wyjątkowo odporne na apoptozę, a w wykwitach stwierdza się nadekspresję Bcl-XL stymulowaną przez TNF- $\alpha$ zmniejszonej apoptozy keratynocytów [37]. Należy zaznaczyć, że neutrofile są obfitym źródłem mediatorów stanu zapalnego, w tym reaktywnych utleniaczy (reactive oxygen species - ROS), mediatorów lipidowych o aktywności chemotaktycznej [38].

Stymulacja TLR wpływa na komórki dendrytyczne, które - podobnie jak w łuszczycy - aktywują mechanizmy adaptacyjnej odpowiedzi immunologicznej. W obecności IL-12 lub IL-23 z limfocytów naiwnych wykształcają się aktywne Th1 i Th17 [39]. Stwierdzono również, że podtyp komórek dendrytycznych CD11c+ określany jako TIP-DC (wytwarzające TNF- $\alpha$ i indukowalną syntetazę tlenku azotu), ściśle związany z patogenezą łuszczycy, może również przyczyniać się do rozwoju POChP $[2,40]$. Komórki TIP DC wydzielają także IL-20 i IL-23, które aktywują keratynocyty oraz powodują proliferację limfocytów Th17 wytwarzających IL-17 [40].

Podobnie jak w łuszczycy, stwierdzono zmniejszenie ilości komórek Treg [28]. Palacze z POChP i rozedmą płuc mieli ich znacznie mniej oraz wykazywali niższą ekspresję mRNA dla FOXP3 w płucach [39].

\section{Rola infekcji w prowokacji łuszczycy i POChP}

Znaczenie infekcji jako czynnika prowokującego wysiew zmian łuszczycowych jest dobrze znane i wyjaśnione przez „teorię superantygenów”. Klasycznym przykładem jest prowokacja choroby przez białko M Streptococcus pyogenes. Dowodem na to jest redukcja zmian skórnych, a nawet remisja choroby po zabiegach tonsillektomii [41, 42]. Inne udowodnione prowokujące czynniki infekcyjne to Staphylococcus aureus, 
perantigen production and toxin activity [21, 42, 43]. A coexistent colonization with Staphylococcus aureus on a mouse model of bronchitis caused by cigarette smoke led to an increase in IL-17 concentration in BAL [21].

\section{COPD as a systemic inflammation}

C-reactive protein is a key biomarker of systemic inflammation and may be used as a predictor of future cardio-vascular incidents [44].

Numerous studies indicate a higher CRP concentration in psoriatic patients as compared with the control group, especially with concomitant metabolic syndrome $[44,45]$. A meta-analysis involving 78 studies $(7,852$ patients, 3,085 with severe psoriasis) showed moderate but significantly increased CRP and pro-inflammatory cytokine (IL-1b, IL-6, TNF- $\alpha$ ) concentrations in sera of psoriatic patients, especially the ones with severe psoriasis [46]. However, one of the recent studies suggests that systemic inflammation associated with an increase in CRP in psoriatic patients, which causes oxidative damage of DNA/ RNA, is a result of inflammation associated with the presence of exanthemata rather than concomitant metabolic syndrome in those patients [47].

Chronic obstructive pulmonary disease patients, especially the ones suffering from severe COPD and during the periods of disease exacerbation, also exhibit signs of systemic inflammation with an increase in CRP concentration, fibrinogen, and blood leucocytosis [47]. Augusti et al. evaluated 6 inflammatory markers (CRP, IL-6, IL-8, fibrinogen, TNF- $\alpha$, and leucocytes) in 1,755 patients with COPD. In $30 \%$ of patients signs of systemic inflammation were not confirmed, while $16 \%$ of patients exhibited persistent signs of this inflammation, despite similar abnormalities in spirometric tests in both groups. In addition, a significantly increased mortality due to different reasons and higher frequency of exacerbations within a year were confirmed in the second group (1.5 vs. $0.9)[48,49]$.

However, it is still uncertain whether these systemic inflammation markers are a result of inflammatory response spreading from the lungs, or whether this is associated with another concomitant disease that exerts an influence on the lungs. In every case a systemic inflammation observed in COPD patients may contribute to its systemic signs and worsen the course of concomitant diseases [48].

\section{TREATMENT OF PSORIASIS AS WELL AS PSORIATIC ARTHRITIS AND COPD}

Concomitant diseases determine a treatment method. A 4-year-long multicentre French study, grzyby (Malassezia, Candida albicans) i wirusy (wirusy brodawczaka, retrowirusy) [41].

Należy zaznaczyć, że przewlekły stan zapalny i tendencja do infekcji bakteryjnych u osób z POChP są czynnikami wyzwalającymi zapalenie łuszczycowe w mechanizmie superantygenów [42]. Kolonizacja bakteryjna występuje zarówno w stabilnej POChP, jak i podczas zaostrzeń. Najczęściej stwierdza się pneumokoki, Haemophilus influenzae, Moraxella catarrhalis i Staphylococcus aureus [21]. Od 50\% do $80 \%$ izolatów Staphylococcus aureus jest dodatnich pod względem co najmniej jednego genu superantygenu, a blisko 50\% wykazuje produkcję superantygenu i aktywność toksyny [21, 42, 43]. Współistniejąca kolonizacja Staphylococcus aureus na modelu mysim zapalenia oskrzeli wywołanego dymem papierosowym powodowała wzrost stężenia IL-17 w BAL [21].

\section{POChP jako zapalenie ogólnoustrojowe}

Białko C-reaktywne jest istotnym biomarkerem ogólnoustrojowego stanu zapalnego i może być wykorzystywane jako wskaźnik prognostyczny wystąpienia incydentów sercowo-naczyniowych w przyszłości [44].

Liczne badania wskazują na podwyższone stężenie CRP u chorych na łuszczycę, zwłaszcza ze współistniejącym zespołem metabolicznym, w porównaniu z grupą kontrolną [44, 45]. Metaanaliza obejmująca 78 badań (7852 chorych, 3085 z łuszczycą ciężką) wykazała umiarkowane, ale znacznie podwyższone stężenia CRP i cytokin prozapalnych (IL-1 $\beta$, IL-6, TNF- $\alpha$ ) w surowicy pacjentów z łuszczycą, zwłaszcza ciężką [46]. Jedno z ostatnich badań sugeruje jednak, że ogólnoustrojowy stan zapalny związany ze wzrostem CRP u chorych na łuszczycę, który powoduje uszkodzenie oksydacyjne DNA/RNA, jest wynikiem raczej zapalenia związanego z obecnością wykwitów chorobowych niż współistniejącego zespołu metabolicznego [47].

U pacjentów z POChP, zwłaszcza w jej ciężkiej postaci i podczas zaostrzeń, występują również objawy ogólnoustrojowego zapalenia ze wzrostem stężenia CRP, fibrynogenu oraz leukocytozą we krwi [47]. Augusti i wsp. ocenili 6 markerów stanu zapalnego (białko C-reaktywne, IL-6, IL-8, fibrynogen, TNF- $\alpha$ i leukocyty) u 1755 pacjentów z POChP. U 30\% pacjentów nie stwierdzono objawów ogólnoustrojowego stanu zapalnego, podczas gdy 16\% miało trwale utrzymujące się cechy zapalenia, mimo podobnych nieprawidłowości w badaniach spirometrycznych w obu grupach. Ponadto w drugiej grupie stwierdzono istotnie zwiększoną śmiertelność z różnych przyczyn i większą częstość zaostrzeń w ciągu roku $(1,5$ vs 0,9$)[48,49]$.

Wciąż nie jest jednak pewne, czy ogólnoustrojowe wskaźniki stanu zapalnego są skutkiem rozprzestrzeniania się reakcji zapalnej z płuc, czy są związane z jakąś współistniejącą chorobą, która następnie ma 
Psobioteq, (830 patients) showed that in case of concomitant COPD patients were more often treated with ustekinumab and etanercept than adalimumab [50]. Physicians motivated their choice by a frequent predisposition for infections and development of tuberculosis in case of TNF- $\alpha$ inhibitors (TNFi) (anti-TNF- $\alpha$ antibodies and fusion protein binding soluble TNF- $\alpha$ receptors) $[50,51]$.

However, TNFi has rational basis for advantageous activity in COPD. Alveolar macrophages of smokers and COPD patients release large amounts of TNF- $\alpha$. Its increased concentration is confirmed in sputum and BAL, especially during exacerbation periods [26, 52].

It was concluded that soluble receptor for tumour necrosis factor type II (sTNFRII) levels in sputum are inversely proportional to $\mathrm{FEV}_{1}$ in COPD patients and serve as prognostic biomarkers for the risk of exacerbation [52, 53]. However, information about the inhibiting influence of TNF on COPD exacerbation is limited.

Accortt $e t$ al. acted on evaluating the influence of TNFi and disease-modifying antirheumatic drugs (DMARD) on COPD concomitant in those patients. Percentage and hospitalization frequency due to COPD (per 100 person-years) of those patients was the lowest in the cohort treated with TNFi, and the results of a multidimensional analysis revealed a beneficial influence of both TNFi and DMARD [54]. However, a specific targeted anti-inflammatory therapy involving infliximab failed to bring expected results in COPD [38].

Despite the fact that usage of TNF- $\alpha$ antagonists in COPD therapy was evaluated in clinical studies, differences in its efficacy as compares with prednisone therapy were not showed $[54,55]$. Nevertheless, beneficial results were achieved in young and cachectic individuals [52].

Lack of high efficacy of TNF antagonists in COPD may probably result from diversity of this disease, where blocking only one cytokine is not sufficient to control it $[13,52,56]$.

New data regarding COPD pathogenesis indicate rational bases to use IL-17 inhibitors. A study conducted on mice showed that anti-IL-17 antibodies caused a decrease in the number of neutrophils, mucin 5AC concentration in BAL, and neutrophil inflammation of the respiratory tract [57].

A new group of drugs used in treatment of psoriasis is worth mentioning, i.e. phosphodiesterase- 4 inhibitors (PDE-4). It is a new class of anti-inflammatory preparations that are well-tolerated and lower the concentration of proinflammatory cytokines by a series of mechanisms [58]. Individual reports confirm their efficacy in therapies for psoriasis with concomitant COPD [59]. wpływ na płuca. W każdym przypadku układowe zapalenie obserwowane u pacjentów z POChP może się przyczynić do wystapienia objawów ogólnoustrojowych i może pogorszyć przebieg współwystępujących chorób [48].

\section{LECZENIE ŁUSZCZYCY I ŁUSZCZYCOWEGO ZAPALENIA STAWÓW A POCHP}

Schorzenia współistniejące determinują wybór metody leczenia. W 4-letnim, wieloośrodkowym badaniu francuskim Psobioteq (830 chorych) wykazano, że w przypadku współistnienia POChP pacjenci częściej byli leczeni ustekinumabem i etanerceptem niż adalimumabem [50]. Swój wybór lekarze motywowali częstszą predyspozycją do infekcji i rozwoju gruźlicy w przypadku inhibitorów TNF (TNFi) (przeciwciała anty-TNF- $\alpha$ i białko fuzyjne, łączące rozpuszczalny receptor dla TNF- $\alpha)[50,51]$.

Stosowanie TNFi ma racjonalne podstawy z uwagi na przesłanki korzystnego działania w POChP. Pęcherzykowe makrofagi osób palących papierosy i pacjentów z POChP uwalniają duże ilości TNF- $\alpha$. Zwiększone jego stężenie stwierdza się w plwocinie i BAL, zwłaszcza w czasie zaostrzeń $[26,52]$.

Stwierdzono, że poziomy sTNFRII (soluble receptor for tumor necrosis factor type II) w plwocinie są odwrotnie proporcjonalne do $\mathrm{FEV}_{1} \mathrm{u}$ pacjentów z POChP i służą jako biomarker prognostyczny dla ryzyka zaostrzenia $[52,53]$. Istnieją jednak ograniczone informacje na temat wpływu hamowania TNF na zaostrzenia POChP.

Accortt i wsp. podjęli się oceny wpływu TNFi i leków przeciwreumatycznych modyfikujących przebieg choroby (disease-modifying antirheumatic drugs - DMARD) na POChP współistniejącą u tych pacjentów. Odsetek pacjentów hospitalizowanych i częstość hospitalizacji z powodu POChP (na 100 osobolat) były najniższe w kohorcie leczonej TNFi, a wyniki analizy wielowymiarowej wykazały korzystny wpływ zarówno TNFi, jak i DMARD [54]. Specyficzna celowana terapia przeciwzapalna $\mathrm{z}$ infliksymabem nie przyniosła jednak oczekiwanych wyników w POChP [38].

Zastosowanie antagonistów TNF- $\alpha$ w terapii POChP oceniano w badaniach klinicznych, jednak nie wykazano różnic dotyczących skuteczności w porównaniu $\mathrm{z}$ terapią prednizonem $[54,55]$. Korzystne wyniki osiągano jednak u osób młodych i wyniszczonych [52].

Braku dużej skuteczności antagonistów TNF w POChP wynika prawdopodobnie $\mathrm{z}$ heterogenności tej choroby, a blokowanie tylko jednej cytokiny nie jest wystarczające do jej kontrolowania $[13,52,56]$.

Nowe dane dotyczące patogenezy POChP dają racjonalne podstawy do stosowania inhibitorów IL-17. W badaniu wykonanym na myszach wy- 


\section{CONCLUSIONS}

Despite the fact that both diseases have a multifactor aetiology, it should be emphasized that there is an increased risk for developing COPD in psoriatic patients. Preventive and therapeutic activities that control risk factors, such as discontinuance of smoking or treatment of inflammation, may prevent COPD development in psoriatic patients [2]. Furthermore, identification of this potential risk may allow for early implementation of preventive measures in order to decrease the number of concomitant diseases and mortality.

\section{CONFLICT OF INTEREST}

The authors declare no conflict of interest. kazano, że przeciwciała anty-IL-17 powodowały zmniejszenie liczby neutrofilów, stężenia mucyny $5 \mathrm{AC}$ w BAL oraz neutrofilowego zapalenia dróg oddechowych [57].

Warto zwrócić uwagę na nową grupę leków stosowanych w terapii łuszczycy - inhibitory fosfodiesterazy 4 (PDE-4). To nowa klasa preparatów przeciwzapalnych, dobrze tolerowanych, które poprzez szereg mechanizmów redukują stężenie cytokin prozapalnych [58]. Pojedyncze doniesienia potwierdzają ich skuteczność w terapii łuszczycy ze współistnieniem POChP [59].

\section{WNIOSKI}

Mimo że obie choroby mają wieloczynnikową etiologię, należy podkreślić podwyższone ryzyko rozwoju POChP u pacjentów z łuszczycą. Działania profilaktyczne i terapeutyczne kontrolujące czynniki ryzyka, takie jak zaprzestanie palenia tytoniu lub leczenie procesu zapalnego, mogą zapobiec pojawieniu się POChP u pacjentów z łuszczycą [2]. Ponadto identyfikacja tego ryzyka może umożliwić wcześniejsze wdrożenie środków zapobiegawczych w celu zmniejszenia liczby chorób współistniejących i śmiertelności.

\section{KONFLIKT INTERESÓW}

Autorzy nie zgłaszają konfliktu interesów.

\section{References}

Piśmiennictwo

1. Balci D.D., Celik E., Genc S., Çelik M.M., Inan M.U.: Impared pulmonary functions in patient with psoriasis. Dermatology 2016, 232, 664-667.

2. Chiang Y.Y., Lin H.W.: Association between psoriasis and chronic obstructive pulmonary disease: a population-based study in Taiwan. J Eur Acad Dermatol Venereol 2012, 26, 59-65.

3. Hurst J.R., Sin D.D.: Chronic obstructive pulmonary disease as a risk factor for cardiovascular disease. a view from the SUMMIT. Am J Respir Crit Care Med 2018, 198, 2-4.

4. Dreiher J., Weitzman D., Shapiro J., Davidovici B., Cohen A.D.: Psoriasis and chronic obstructive pulmonary disease: a case control study. Br J Dermatol 2008, 159, 956-960.

5. Wu Y., Mills D., Bala M.: Psoriasis: cardiovascular risk factors and other disease comorbidities. J Drugs Dermatol 2008, 7, 373-377.

6. Wu C.Y., Hu H.Y., Li C.P., Chou Y.J., Chang Y.T.: Comorbidity profiles of psoriasis in Taiwan: a latent class analysis. PLoS One 2018, 13, e0192537.

7. Ungprasert P., Srivali N., Thongprayoon C.: Association between psoriasis and chronic obstructive pulmonary disease: a systematic review and meta-analysis. J Dermatolog Treat 2016, 27, 316-321.

8. Al-Mutairi N., Al-Farag S., Al-Mutairi A., Al-Shiltawy M.: Comorbidities associated with psoriasis: an experience from the Middle East. J Dermatol 2010, 37, 146-155.

9. Li X., Kong L., Li F., Chen C., Xu R., Wang H., et al.: Association between psoriasis and chronic obstructive pulmonary disease: a systematic review and meta-analysis. PLoS One 2015, 10, e0145221.

10. Wong K., Gladman D.D., Husted J., Long J.A., Farewell V.T.: Mortality studies in psoriatic arthritis: results from a single outpatient clinic. I. Causes and risk of death. Arthritis Rheum 1997, 40, 1868-1872.

11. Brown J.P., Martinez C.H.: Chronic obstructive pulmonary disease comorbidities. Curr Opin Pulm Med 2016, 22, 113-118.

12. Vogelmeier C.F., Criner G.J., Martínez F.J., Anzueto A., Barnes P.J., Bourbeau J., et al.: Global Strategy for the Diagnosis, Management, and Prevention of Chronic Obstructive Lung Disease 2017 Report: GOLD Executive Summary. Arch Bronconeumol 2017, 53, 128-149.

13. Pavord I.D.: Biologics and chronic obstructive pulmonary disease. J Allergy Clin Immunol 2018, 141, 1983-1991.

14. Śliwiński P., Jassem E., Pierzkała W.: Zalecenia Polskiego Towarzystwa Chorób Płuc dotyczące rozpoznawania i leczenia przewlekłej obturacyjnej choroby płuc. Pneumonol Alergol Pol 2014, 82, 227-263. 
15. Hansen P.R., Isaken J.L., Jemec G.B., Kanters J.K., Ellervik C.: Pulmonary function in patients with psoriasis: across-sectional population study. Br J Dermatol 2018, 179, 518-519.

16. Jin Y., Yang S., Zhang F., Kong Y., Xiao F., Hou Y., et al.: Combined effects of HLA-Cw6 and cigarette smoking in psoriasis vulgaris: a hospital-based case-control study in China. J Eur Acad Dermatol Venereol 2009, 23, 132-137.

17. Setty A.R., Curhan G., Choi H.K.: Smoking and the risk of psoriasis in women: Nurses' Health Study II. Am J Med 2007, 120, 953-959.

18. Fortes C., Mastroeni S., Leffondré K., Sampogna F., Melchi F., Mazzotti E., et al.: Relationship between smoking and the clinical severity of psoriasis. Arch Dermatol 2005, 141, 1580-1584.

19. Armstrong A.W., Harskamp C.T., Dhillon J.S., Armstrong E.J.: Psoriasis and smoking: a systematic review and meta-analysis. Br J Dermatol 2014, 170, 304-314.

20. Raychaudhuri S.P., Gross J.: Psoriasis risk factors: role of lifestyle practices. Cutis 2000, 66, 348-352.

21. Huvenne W., Lanckacker E.A., Krysko O., Bracke K.R., Demoor T., Hellings P.W., et al.: Exacerbation of cigarette smoke induced pulmonary inflammation by Staphylococcus aureus enterotoxin B in mice. Respir Res 2011, 12, 69.

22. Tanni S.E., Pelegrino N.R., Angeleli A.Y., Correa C., Godoy I.: Smoking status and tumor necrosis factor-alpha mediated systemic inflammation in COPD patients. J Inflamm (Lond) 2010, 7, 29.

23. Damiani G., Radaeli A., Olivini A., Calvara-Pinton P., Malerba M.: Increased airway inflammation in patients with psoriasis. Br J Dermatol 2016, 175, 797-799.

24. Kim V., Rogers T.J., Criner G.J.: New concepts in the pathobiology of chronic obstructive pulmonary disease. Proc Am Thorac Soc 2008, 5, 478-485.

25. Cosio M.G., Saetta M., Agusti A.: Immunologic aspects of chronic obstructive pulmonary disease. N Engl J Med 2009, 360, 2445-2454.

26. Chang Y., Nadigel J., Boulais N., Bourbeau J., Maltais F., Eidelman D.H., et al.: CD8 positive T cells express IL-17 in patients with chronic obstructive pulmonary disease. Respir Res 2011, 12, 43.

27. Tan H.L., Rosenthal M.: IL-17 in lung disease: friend or foe? Thorax 2013, 68, 788-790.

28. Sapey E., Wood A.M., Ahmad A., Stockley R.A.: TNF\{alpha\} rs361525 polymorphism is associated with increased local production and downstream inflammation in COPD. Am J Respir Crit Care Med 2010, 182, 192-199.

29. Roos A.B., Sandén C., Mori M., Bjermer L., Stampfli M.R., Erjefalt J.S.: IL -17A is elevated in endstage chronic obstructive pulmonary disease and contributes to cigarette smoke-induced lymphoid neogenesis. Am J Respir Crit Care Med 2015, 191, 1232-1241.

30. Fujisawa T., Velichko S., Thai P., Hung L.Y., Huang F., Wu R.: Regulation of airway MUC5AC expression by IL-1beta and IL-17A; the NF-kappaB paradigm. J Immunol 2009, 183, 6236-6243.

31. McKinley L., Alcorn J.F., Peterson A., Dupont R.B., Kapadia S., Logar A., et al.: Th17 cells mediate steroid-resistant airway inflammation and airway hyperresponsiveness in mice. J Immunol 2008, 181, 4089-4097.

32. Dicker A.J., Crichton M.L., Pumphrey E.G., Cassidy A.J., Suarez-Cuartin G., Sibila O., et al.: Neutrophil extracellular traps are associated with disease severity and microbiota diversity in patients with chronic obstructive pulmonary disease. J Allergy Clin Immunol 2018, 141, 117-127.

33. Kaplan M.J., Radic M.: Neutrophil extracellular traps: double-edged swords of innate immunity. J Immunol 2012, 189, 26892695.

34. Hu S.C., Yu H.S., Yen F.L., Lin C.L., Chen G.S., Lan C.C.: Neutrophil extracellular trap formation is increased in psoriasis and induces human beta-defensin-2 production in epidermal keratinocytes. Sci Rep 2016, 6, 31119.

35. Machado-Pinto J., Diniz Mdos S., Bavoso N.C.: Psoriasis: new comorbidities. An Bras Dermatol 2016, 91 , 8-14.

36. Cosio M.G., Saetta M., Agusti A.: Immunologic aspects of chronic obstructive pulmonary disease. N Eng1 J Med 2009, 360, 2445-2454.

37. Kastelan M., Prpić-Massari L., Brajac I.: Apoptosis in psoriasis. Acta Dermatovenerol Croat 2009, 17, $182-186$.

38. Brusselle G.G., Joos G.F., Bracke K.R.: New insights into the immunology of chronic obstructive pulmonary disease. Lancet 2011, 378, 1015-1026.

39. Nedoszytko B., Roszkiewicz J.: Znaczenie subpopulacji komórek dendrytycznych w patogenezie łuszczycy. Adv Dermatol Allergol 2007, 26, 263-270.

40. Owczarczyk-Saczonek A., Czerwińska J., Placek W.: The role of regulatory T cells and anti-inflammatory cytokines in psoriasis. Acta Dermatovenerol Alp Pannonica Adriat 2018, 27, 17-23.

41. Malerba M., Radaeli A., Olivini A., Damiani G., Ragnoli B., Montuschi P., et al.: Exhaled nitric oxide as a biomarker in COPD and related comorbidities. Biomed Res Int 2014, 2014, 271918.

42. Thorleifsdottir R.H., Eysteinsdóttir J.H., Olafsson J.H., Sigurdsson M.I., Johnston A., Valdimarsson H., et al.: Throat infections are associated with exacerbation in a substantial proportion of patients with chronic plaque psoriasis. Acta Derm Venereol 2016, 96, 788-791.

43. Chau T.A., McCully M.L., Brintnell W., An G., Kasper K.J., Vinés E.D., et al.: Toll-like receptor 2 ligands on the staphylococcal cell wall downregulate superantigen-induced T cell activation and prevent toxic shock syndrome. Nat Med 2009, 15, 641-648.

44. Owczarczyk-Saczonek A.B., Nowicki R.J.: Prevalence of cardiovascular disease risk factors, and metabolic syndrome and its components in patients with psoriasis aged 30 to 49 years. Adv Dermatol Allergol 2015, 32, $290-295$.

45. Chodorowska G., Wojnowska D., Juszkiewicz-Borowiec M.: C-reactive protein and alpha2-macroglobulin plasma activity in medium-severe psoriasis. J Eur Acad Dermatol Venereol 2004, 18, 180-183.

46. Dowlatshahi E.A., van der Voort E.A., Arends L.R., Nijsten T.: Markers of systemic inflammation in psoriasis: a systematic review and meta-analysis. Br J Dermatol 2013, 169, 266-282.

47. Borska L., Kremlacek J., Andrys C., Krejsek J., Hamakova K., Borsky P., et al.: Systemic inflammation, oxidative damage to nucleic acids, and metabolic syndrome in the pathogenesis of psoriasis. Int J Mol Sci 2017, 18, pii: E2238. 
48. Barnes P.J.: Inflammatory mechanisms in patients with chronic obstructive pulmonary disease. J Allergy Clin Immunol 2016, $138,16-27$.

49. Agusti A., Edwards L.D., Rennard S.I., Macnee W., Tal-Singer R., Miller B.E., et al.: Persistent systemic inflammation is associated with poor clinical outcomes in COPD: a novel phenotype. PLoS One 2012, 7, e37483.

50. Sbidian E., Giboin C., Bachelez H., Paul C., Beylot-Barry M., Dupuy A., et al.: Factors associated with the choice of the first biologic in psoriasis: real-life analysis from the Psobioteq cohort. J Eur Acad Dermatol Venereol 2017, 31, $2046-2054$.

51. Nast A., Gisondi P., Ormerod A.D., Saiag P., Smith C., Spuls P.I., et al.: European S3-Guidelines on the systemic treatment of psoriasis vulgaris - Update 2015 - Short version - EDF in cooperation with EADV and IPC. J Eur Acad Dermatol Venereol 2015, 29, 2277-2294.

52. Malaviya R., Laskin J.D., Laskin D.L.: Anti-TNF-alpha therapy in inflammatory lung diseases. Pharmacol Ther 2017, 180, 90-98.

53. Woodruff P.G., Chatila W., Connett J.E., Criner G.J., Curtis J.L., Dransfield M.T., et al.: Tumour necrosis factor receptor-75 and risk of COPD exacerbation in the azithromycin trial. Eur Respir J 2014, 43, 295-298.

54. Accortt N.A., Chung J.B., Bonafede M., Limone B.L., Mannino D.M.: Retrospective analysis to describe associations between tumor necrosis factor alpha inhibitors and COPD-related hospitalizations. Int J Chron Obstruct Pulmon Dis 2017, 12, 20852094.

55. Aaron S.D., Vandemheen K.L., Maltais F., Field S.K., Sin D.D., Bourbeau J., et al.: TNF-alpha antagonists for acute exacerbations of COPD: a randomised double-blind controlled trial. Thorax 2013, 68, 142-148.

56. Rennard S.I., Fogarty C., Kelsen S., Long W., Ramsdell J., Allison J., et al.: The safety and efficacy of infliximab in moderate to severe chronic obstructive pulmonary disease. Am J Respir Crit Care Med 2007, 175, 926-934.

57. Shen N., Wang J., Zhao M., Pei F., He B.: Anti-interleukin-17 antibodies attenuate airway inflammation in tobacco-smokeexposed mice. Inhal Toxicol 2011, 23, 212-218.

58. Wittmann M., Helliwell P.S.: Phosphodiesterase 4 inhibition in the treatment of psoriasis, psoriatic arthritis and other chronic inflammatory diseases. Dermatol Ther (Heidelb) 2013, 3, 1-15.

59. Michels K., Hagner M., El Zein M., Dasa O., Assaly R.: Treating 2 diseases with 1 drug: PDE-4 inhibitor for COPD and psoriasis. Am J Ther 2017, 24, e103-e104.

Received: 19.08 .2018

Accepted: 30.03.2019

Otrzymano: 19.08.2018 r.

Zaakceptowano: 30.03.2019 r.

How to cite this article

Owczarczyk-Saczonek A.B., Owczarczyk J., Krajewska-Włodarczyk M., Wojtkiewicz J., Placek W.: Are psoriasis and psoriatic arthritis associated with chronic obstructive pulmonary disease? Dermatol Rev/Przegl Dermatol 2019, 103, $185-197$.

DOI: https://doi.org/10.5114/dr.2019.85576. 